\title{
Public perception of carbon capture (utilization) and storage projects: world experience and the situation in Russia
}

\author{
V D Simonchuk, N V Romasheva \\ Department of Economics, Organization and Management, Faculty of Economics, St. Petersburg \\ Mining University, Saint Petersburg, Russia
}

\begin{abstract}
At present, one of the major global environmental problems is the greenhouse effect, which is caused by carbon dioxide emissions. One of the most innovative methods to combat the greenhouse effect is the introduction of $\mathrm{CC}(\mathrm{U}) \mathrm{S}$ projects, involving the implementation of $\mathrm{CC}(\mathrm{U}) \mathrm{S}$ technologies, aimed to carbon capture (CC), storage in underground facilities (S), and sometimes utilization (U). This paperexamines foreign experience of applying $\mathrm{CC}(\mathrm{U})$ Stechnologies, which have shownthat some projects have been canceled due to negative public reaction because of low awareness. To understand the prospects for the implementation of CC(U)S projects in Russia, student surveys were conducted among St. Petersburg universities in order to determine the level of awareness of Russian society about this issue. As a result, recommendations were developed to increase awareness level of society of $\mathrm{CC}(\mathrm{U}) \mathrm{S}$ technologies The study is based on publications of Russian and international experts in different scientificjournals. The research methodology includes desk studies, methods of comparative analysis and systematization, a sociological study, a method of generalization, and grouping.
\end{abstract}

\section{Introduction}

For many years, numerous scientists and experts have been concerned about the topic of global climate change, which implies an increase in the average annual temperature, which causes glaciers to melt and sea levels to rise [1-4].

Many experts associate climate change on the planet with the emission of anthropogenic greenhouse gases, which include carbon dioxide $\left(\mathrm{CO}_{2}\right)$. In this way, many states, companies, and communities are greatly interested in the problems of $\mathrm{CO}_{2}$ emissions, as well as the development of technologies that can reduce them [5-8]. According to the Analytical Center under the government of the Russian Federation (Analytical Center under the government of the Russian Federation Report 2019), the total global $\mathrm{CO}_{2}$ emissions in 2018 reached 33.9 billion tons, an increase of $1.9 \%$ (the maximum growth rate over the past seven years). Emerging economies made the largest contribution to the increase in emissions, while countries in the European Union reduced emissions.

An innovative measure to tackle carbon emissions is the use and spreading of CC(U)S (carbon capture, utilization, and storage) technologies [9-11]. These technologies can significantly reduce greenhouse gas emissions, which lead to global warming. The CC(U)S 
technologies represent the process of $\mathrm{CO}_{2}$ capture at the source of its emission, transportation, and long-term storage with mandatory monitoring of storage facilities (traps) and sometimes utilization (Global CCS Institute 2019).

These technologiesare characterized by the following features: 1) Economic: high capital and operating costs $[12,13]$; 2) Technological: complexity, point testing of technologies (at this stage of technology development, it is often impossible to implement projects) [13]; 3) Environmental: $\mathrm{CC}(\mathrm{U}) \mathrm{S}$ issues cause ambiguity of opinions about the safety of projects in terms of $\mathrm{CO}_{2}$ storage (not enough experience in implementing similar projects, a short period during which gas behavior has been observed in underground placement) $[12,14]$; 4) Social: positive public perception of suchtechnologiesis hard to achieve, as people doubt about the safety of $\mathrm{CO}_{2}$ storage $[15,16]$.

The fact that $\mathrm{CO}_{2}$ injection into underground tanks can cause accidents and leaks is used as an argument by opponents of this technology. Doubts about the safety of this way of dealing with the problem of global warming lead to a negative perception of society, which has already caused the cancellation of several projects around the world [11,17-20].

At present, none of the world $\mathrm{CC}(\mathrm{U}) \mathrm{S}$ projects is being implemented on the territory of the Russian Federation; however, for a number of reasons, their implementation is quite promising and may lead to economic and social effects in the future.

In this regard, the study of public perception of such complex technologies as CC(U)S is relevant.

This article attempts to study the problems of public perception of $\mathrm{CC}(\mathrm{U}) \mathrm{S}$ projects and to develop recommendations for raising the awareness of Russian society about such projects.

\section{Review of literature}

$\mathrm{CC}(\mathrm{U}) \mathrm{S}$ technologies are actively studied by the Global Institute of of Carbon Capture and Storage [21], National Energy Technology Laboratory, World Energy Council, International Energy Agency, Carbon Capture and Storage Association [22].

English scientist Mhairi Aitken [13], a group of scientists from Canada [23], a group of scientists from the Netherlands [24], and many other researchers are engaged in studying of public perception of CC(U)S technologies [25,26].

A large number of researchers highlight the technological side of CC(U)S [27]. Many publications deal with issues related to the commercial effectiveness of technology applications [10,28,29].

In Russia, this technology is studied by a scientific team of Mining University under the guidance of Professor A. Cherepovitsyn [6,30] and other Russian scientists [31-33].

Nevertheless, despite a large number of different publications on the research topic, some aspects, namely, the social side of the application of CC(U)S technology has not been adequately studied.

Thus, this study analyzes the prospects for the application of $\mathrm{CC}(\mathrm{U}) \mathrm{S}$ technology in Russia, specifically, the social aspects of the issue: the public perception of such projects, identifying the level of public awareness.

\section{Research methods and materials}

In the research, the following methods were used: 1) desk studies to collect and summarize information about various $\mathrm{CC}(\mathrm{U}) \mathrm{S}$ projects with the necessary information obtained from available sources, such as websites of companies and sequestration projects, the global database of the CCS Institute, the database of the National Energy Technology Laboratory 
(NETL) and the theoretical basis of the study composed on publications of scientists and experts in scientific electronic and printed sources, such as Notes of the Mining Institute, Energy Procedia, Energy Policy, Resources, and others; 2) methods of comparative analysis and systematization to determine the nature of $\mathrm{CC}(\mathrm{U}) \mathrm{S}$ projects, as well as the specifics of perception of such projects in society; 3) a sociological study, i.e., a survey among students of St. Petersburg universities (Mining University, Polytechnic University, St. Petersburg State University), 4) a method of generalization and grouping to process the results obtained during the surveying.

\section{Results}

During the study, it was found out that public perception plays a key role in the spreading and implementation of $\mathrm{CC}(\mathrm{U}) \mathrm{S}$ projects at local and global levels. At the same time, public perception is a social institution consisting of three elements: 1) psychological (feelings, emotions), 2) ethical (morality), 3) relational (awareness) [10]. Using CC(U)S technologies is rather difficult and limited today because of the low awareness of nature and safety level [10,34].

At the international level, problems related to public perception are identified as one of the main issues hindering the implementation of technologically complex projects. In world practice, there are many examples where uncoordinated actions of a member of the public led to the closure of a project [10].

As an example of the impact of public opposition on the implementation ofCC(U)S projects, we can bring such projects as Schwartze Pumpe, Greenville, Barendrecht, CarbonNet, WESTCARB Cholla; MRCSP R.E. Burger; SECARB Escatawpa; WESTCARB Rosetta (Table 1) [24,30,35].

Table 1. Characteristics of $\mathrm{CC}(\mathrm{U}) \mathrm{S} \mathrm{CO}_{2}$ projects that were rejected due to public disapproval [24,30,35]

\begin{tabular}{|c|c|c|c|}
\hline $\begin{array}{c}\text { Name of the } \\
\text { project }\end{array}$ & Location & $\begin{array}{c}\text { Ultimate purpose of } \\
\text { application }\end{array}$ & Reason of rejection \\
\hline $\begin{array}{l}\text { Schwartze } \\
\text { Pumpe }\end{array}$ & $\begin{array}{c}\text { Company } \\
\text { «Vattenfall» } \\
\text { (Germany), } \\
2010\end{array}$ & $\begin{array}{c}\text { The coal-fired power } \\
\text { plant uses sequestration } \\
\text { technology }\end{array}$ & $\begin{array}{l}\text { Rejected due to targeted } \\
\text { action of non- } \\
\text { governmental } \\
\text { organizations, whose } \\
\text { members make up about } \\
40 \% \text { of the government. } \\
\text { They did not agree on laws } \\
\text { on the use of sequestration } \\
\text { technologies at the highest } \\
\text { level. }\end{array}$ \\
\hline Barendrecht & $\begin{array}{c}\text { Ohio (USA), } \\
2010\end{array}$ & $\begin{array}{c}\text { Ethanol plant uses } \\
\text { sequestration } \\
\text { technology }\end{array}$ & $\begin{array}{l}\text { Locals successfully } \\
\text { opposed underground } \mathrm{CO}_{2} \\
\text { storage due to a lack of } \\
\text { confidence in the safety of } \\
\text { sequestration technology. } \\
\text { The project was rejected } \\
\text { due to collected petitions } \\
\text { from the public } \\
\text { Non-governmental }\end{array}$ \\
\hline
\end{tabular}


Shell-Pernis refinery

CarbonNet

Victoria
(Australia),
2009

Storage of $\mathrm{CO}_{2}$ at the bottom of the sea

Storage of $\mathrm{CO}_{2}$ at an ocean floor tank
organizations did not agree on the implementation of the project, as they were against using the sequestration technology. In 2012, this situation prompted the government not only to close this project but also to stop all such projects in the Netherlands

Locals expressed concerns about the impact that $\mathrm{CO}_{2}$ storage would have on the "untouched" environment and dissatisfaction with the level of information the government provided them.

The project was rejected due to collected petitions from the public

Due to the public, the project was cancelled at the integration stage. The project was rejected due to collected petitions from the public.

In addition to $\mathrm{CC}(\mathrm{U}) \mathrm{S}$ projects that were not implemented due to distrust of the public, there are examples of other projects that were not implemented precisely due to the same reason (Table 2) [10,23,36].

Table 2. Environmental projects that were rejected because of the public $[10,23,36]$.

\begin{tabular}{|c|c|c|c|}
\hline $\begin{array}{c}\text { Name of the } \\
\text { project }\end{array}$ & Location & $\begin{array}{c}\text { Ultimate purpose of } \\
\text { application }\end{array}$ & Reason of rejection \\
\hline $\begin{array}{l}\text { Solid waste } \\
\text { management }\end{array}$ & $\begin{array}{c}\text { Zhejiang, } \\
\text { China }\end{array}$ & $\begin{array}{l}\text { The burning of } \\
\text { municipal solid waste, } \\
\text { resulting in the } \\
\text { generation of heat, } \\
\text { which can be used in } \\
\text { the form of energy }\end{array}$ & $\begin{array}{l}\text { Locals residents were } \\
\text { concerned about the } \\
\text { harmful emissions that } \\
\text { could result from burning } \\
\text { substances. Thanks to } \\
\text { signed petitions, the plants } \\
\text { had to be closed. }\end{array}$ \\
\hline wind farms & $\begin{array}{l}\text { Finland, } \\
\text { Europe }\end{array}$ & $\begin{array}{l}\text { Use of wind turbines } \\
\text { for energy use }\end{array}$ & $\begin{array}{l}\text { At the stage of project } \\
\text { integration, the local } \\
\text { population was against the } \\
\text { construction of wind } \\
\text { power plants; protests } \\
\text { were organized. }\end{array}$ \\
\hline
\end{tabular}


Based on the above examples and lessons learned, it becomes clear that the public reaction is closely linked to the possibility of implementing various kinds of projects. An important component, in this case, is the public perception of the project itself, the technologies used, its advantages and disadvantages, and possible consequences. In contrast to those projects that were canceled at the initiative of the publicbecause of low awareness, one can cite those that, on the contrary, there were implemented many projects with high support from the society. Such projects include Gorgon, Snøhvit $\mathrm{CO}_{2}$ Storage Project; Petrobras Lula Oil Field CCS Project; Abu Dhabi CCS Project; In Salah Carbon Dioxide Capture and Storage Project [30,37-39].

Summarizing all the above, we can conclude that there are:

a) Factors that contributed to the rejection of $\mathrm{CC}(\mathrm{U}) \mathrm{S}$ projects often include negative public opinion, caused by low awareness of organizations, the local community, the media, the general population about the nature and features of projects, and a lack of work with interested parties; b) Factors that contributed to the implementation of $\mathrm{CC}(\mathrm{U}) \mathrm{S}$ projects, such asclose interaction with stakeholders, especially with the local population, the government, involvement of stakeholders in the decision-making process of the project (for example, involving environmental communities in the environmental assessment of the technology used).

At present, none of the global $\mathrm{CC}(\mathrm{U}) \mathrm{S}$ projects is being implemented in the Russian Federation; however, the implementation of $\mathrm{CC}(\mathrm{U}) \mathrm{S}$ projects involving the injection of $\mathrm{CO}_{2}$ into underground reservoirs, for example, into depleted hydrocarbon deposits, is perspective and can lead to economic and significant social effects in the future: 1) It helps to reduce carbon dioxide emissions, 2) Depleted oil fields can be used to reduce technogenic impactof $\mathrm{CO}_{2}$ emissions (there are opportunities for storage), 3) $\mathrm{CC}(\mathrm{U}) \mathrm{S}$ technology will increase oil recovery and oil quality.

The main constraint for the development of CC(U)S technologies is the public concern about the potential for leaks of buried $\mathrm{CO}_{2}$. Since many $\mathrm{CC}(\mathrm{U}) \mathrm{S}$ projects on a global scale have been canceled at the initial stage of implementation due to public opinion, the next stage of the study was to determine the level of awareness of the Russian society on the implementation of $\mathrm{CC}(\mathrm{U}) \mathrm{S}$ projects. To understand the awareness of Russian society about this problem, surveys among Russian students, teachers, as well as representatives of scientific organizations and industry, were planned.

At the initial stage, a questionnaire was developed and surveys were conducted at several universities in St. Petersburg (Mining University, Polytechnic University, St. Petersburg State University). The survey was conducted using the Google form and the statistic program. The sample size of respondents amounted to about $5 \%$ of all students in the university. In total, about 3941 students of 1-5 grades, as well as postgraduate students, took part in the survey of St. Petersburg universities.

After analyzing the answers, it became clear that only $47.1 \%$ of students of Mining University express serious concerns regarding the issue of carbon dioxide emissions, while about $40 \%$ of students from other universities have rather vague ideas about this problem and do not express serious concerns (Figure 1). 

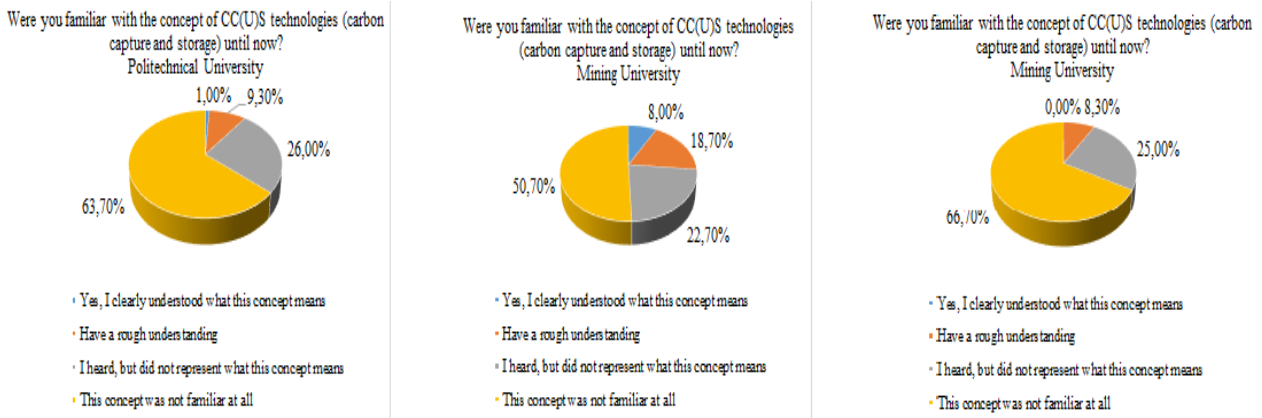

Fig. 1. Students' attitudes toward greenhouse gas emissions (created by the authors).

Regarding the perception of respondents about such method as carbon capture (utilization) and storage of carbon dioxide, half students of Mining Universityhave no idea about $\mathrm{CC}(\mathrm{U}) \mathrm{S}$ projects, and only $8 \%$ are aware of this technology, and $90 \%$ of students of the other universities are not aware of this technology at all (figure 2).
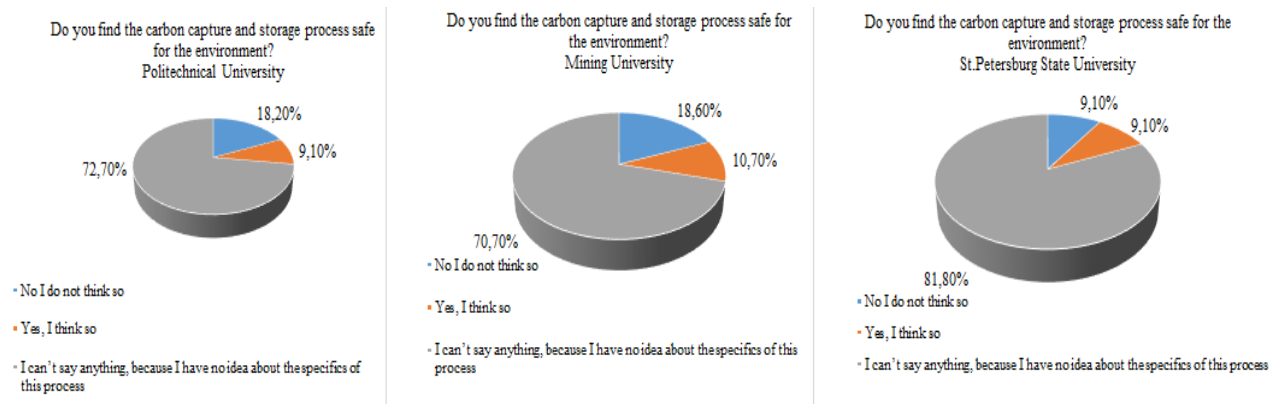

Fig. 2. Students Awareness of the Concept of $\mathrm{CC}(\mathrm{U}) \mathrm{S}$ projects(created by the authors).

Students' awarenessof the implementation of $\mathrm{CC}(\mathrm{U}) \mathrm{S}$ projects in the world also has a low rate. About 74\% students of Mining, St. Petersburg State, and Polytechnic universities do not know whether such projects were implemented.

To the question "AreCC(U)S projects safe?" the majority of respondents answered, "I can't say anything, because I have no idea about that."

Therefore, as described above, due to ignorance, lack of information about CC(U)S projects, the safety of this phenomenon, people may be against using such innovative technology and potentially oppose the implementation of such projects (Figure 3).
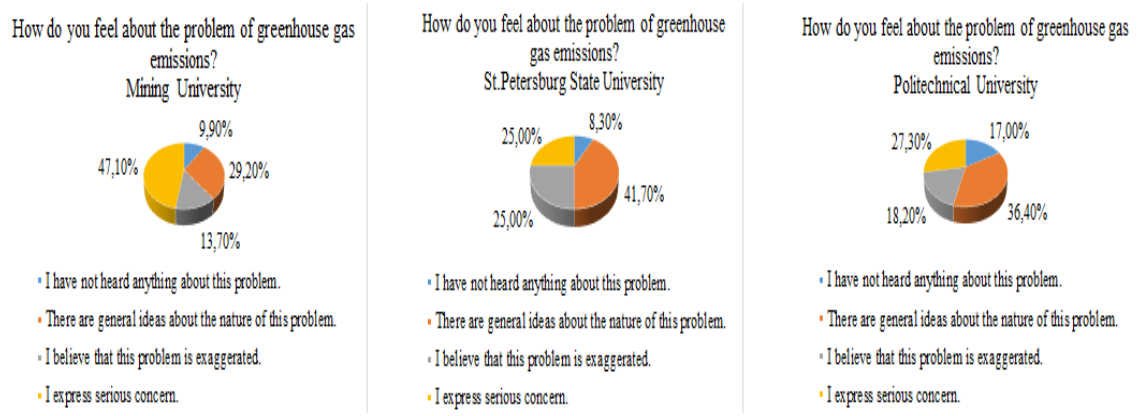

Fig. 3. Perception of safety of using carbon capture (utilization) and storage technology (compiled by the author). 
More than a half, 51.4\% of students, expressed interest in the topic of carbon capture and disposal. They would like to understand what carbon capture (utilization) and storage of carbon dioxide are, to learn more about it.

Comparing the results of surveys of students from different universities, it is clear that the awarenessof students of Mining University is higher than at other universities. It can be explained by the fact that at Mining University the discipline of environmental studies is broadly taught, and students have the opportunity to get acquainted with environmental problems. The awarenessof students of St. Petersburg State University and Polytechnic University about the problem of greenhouse effects, methods of reducing the amount of carbon dioxide emissions (sequestration) is much lovwe than that of students of the Mining University. Moreover, the lack of information affects their perception regarding the safety of this technology, which can lead to a negative reaction in the case of $\mathrm{CC}(\mathrm{U}) \mathrm{S}$ project implementation.

\section{Conclusion}

The study presents characteristics ofCC(U)S projects that have been rejected at the initiative of society, examines concepts of public perception, and surveys a large number of students of St. Petersburg universities, which is sufficient to draw conclusions about how the younger generation understands the problem of greenhouse gas emissions, methods for reducing emissions, and current trends in this area. Surveys among students showed that although many people are aware of the environmental problem of greenhouse emissions, not everyone knows what methods exist to deal with it. If we talk about $\mathrm{CC}(\mathrm{U}) \mathrm{S}$, only a few students know what it is, while others are not informed and cannot be sure of its safety. As part of the study, the following recommendations were made to increase the awareness of Russian society aboutCC(U)S projects:

1) As the rejection of $\mathrm{CC}(\mathrm{U}) \mathrm{S}$ projects is associated with a negative public reaction due to low awareness, it is necessary to raise public awareness as follows:

- Present information to the preschool generation about existing technologies with the help of pictures, comics

- Conduct special lessons at schools on environmental issues, methods to combat them

- Arrange conferences to inform about existing technologies that help to combat emissions of carbon dioxide

- To increase the interest of students and teachers with the topic of protection and preserving of the environment, as well asCC(U)S technologies, in order to develop scientific activities in this field

- To include sections on environmental protection and environmental education in the educational programs of a number of disciplines in all universities

2) In the process of project integration and planning, involve stakeholders, especially the local population, in the decision-making process on the implementation of the project: take into account their opinion, hold meetings to increase public awareness of $\mathrm{CC}(\mathrm{U}) \mathrm{S}$ technologies, their safety, and create a positive public opinion.

The task of raising people's awareness of environmental problems, of the technologies used to eliminate them is essential. Awareness-raising awareness is vital from an early age to instill public confidence in technology. After all, if this is not be done, the implementation of many projects that will help solve environmental problems will become impossible.

The research was carried out with the financial support of a grant from the Russian Science Foundation (Project No. 18-18-00210, "Development of assessment methodology of public efficiency of projects devoted to carbon dioxide sequestration"). 


\section{References}

1. M. Cai, I. Murtazashvili, J. Brick, R. Salahodjaev, Patience and climate change mitigation: Global evidence, Environmental Research 186 (2020).

2. J. Echavarren, A. Balžekienè, A. Telešienè, Multilevel analysis of climate change risk perception in Europe: Natural hazards, political contexts and mediating individual effects, Safety Science 120, 813-823 (2019).

3. R. Itxaso, S. Faria, M. Neumann, Climate change perception: Driving forces and their interactions, Environmental Science \& Policy 108,112-120 (2020).

4. T. Chvileva, Russian practice of information disclosure on greenhouse gas emissions in non-financial reporting, International Multidisciplinary Scientific GeoConference Surveying Geology and Mining Ecology Management, SGEM, 17(53), 775-782 (2017).

5. K. Hornafius, S. Hornafius, Carbon negative oil: A pathway for $\mathrm{CO} 2$ emission reduction goals, International Journal of Greenhouse Gas 37,492-503 (2015).

6. N. Romasheva, A. Ilinova, CCS Projects: How Regulatory Framework Influences Their Deployment, Resources, 8, 181, (2019).

7. A. Tsvetkova, E. Katysheva, Assessment of positive and negative aspects of $\mathrm{CO}_{2}$ sequestration projects by argument map development, International Multidisciplinary Scientific GeoConference Surveying Geology and Mining Ecology Management, SGEM, 18(5.1), 75-80 (2018).

8. D. Jillian, L. Young, D. Lumley, Portfolio Analysis of Carbon Sequestration Technologies and Barriers to Adoption: General Methodology and Application to Geological Storage, Energy Procedia 37, 5063-5079 (2013).

9. A. Hosa, M. Esentia, J. Stewart, S. Haszeldine, Benchmarking worldwide CO2 saline aquifer injections (2010).

10. K. Riahi, E. Rubin, L. Schrattenholzer, Prospects for carbon capture and sequestration technologies assuming their technological learning, Energy 29 (9) 1309-1318 (2004).

11. M. Flett, et al, Gorgon Project: Subsurface evaluation of carbon dioxide disposal under Barrow, Island SPE Asia Pacific Oil and Gas conference: 1855 - 1964 (2008).

12. C. Feenstra, T. Mikunda, S. Brunsting, What happened in Barendrecht? Case study on the planned onshore carbon dioxide storage in Barendrecht, the Netherlands, Energy research Centre of the Netherlands ECN, 44-56 (2010).

13. Mhairi, A. Why we still don't understand the social aspects of wind power: A critique of key assumptions within the literature,Energy Policy, 4: 1834-1841 (2010).

14. M. Flett, et al, Subsurface development of $\mathrm{CO} 2$ disposal for the Gorgon Project, Energy Procedia, 1, 3031-3038 (2009).

15. A. Bjørn, S. Kerndrup, I. Lyhne, Beyond public acceptance of energy infrastructure: How citizens make sense and form reactions by enacting networks of entities in infrastructure development, Energy policy, 96, 576-586 (2016).

16. R. Chaudhry, S. Larson, M. Fischiein, D. Hall, Policy stakeholders' perceptions of carbon capture and storage: a comparison of four US States, Journal of cleaner production, 52, 21-32 (2013).

17. L. Dapeng, W. Weiwei, Barriers and incentives of CCS deployment in China: Results from semi-structured interviews, Energy Policy 37, 2421-2432 (2009).

18. C. Röst, Psychologists test societal acceptance of underground storage of $\mathrm{CO} 2$. Available at: https:/www.universiteitleiden.nl/en/news/2018/09/psychologists-testsocietal-acceptance-of-underground-storage-of-co2 (2018) 
19. S. Vercelli et al, Informing People about CCS: A Review of Social Research Studies,Energy Procedia 37,7464-7473 (2013).

20. L. Yong, S. Chenjunyan, X. Bo, C. Caiyun, C. Vaughan, Impact of community engagement on public acceptance towards waste-to-energy incineration projects: Empirical evidence from China, Waste Management, 76, 431-442 (2018).

21. Global CCS Institute. Deployment of CCS in the Cement Industry. Available at: http://hub.globalccsinsti (2019).

22. Independent Statistics and Analysis. U.S. Energy Information Administration. Available at: https://www.eia.gov/ (2019).

23. M. Uno, Y. Mori, Y. Endo, Experimental study regarding public perception of $\mathrm{CO} 2$ underground sequestration technologies, Greenhouse Gas Control Technologies 7, 2481-2484 (2005).

24. E. Mors, M. Weening, N. Ellemers, Public information: On why and when multiple information sources are more effective than single information sources in communication about CCS, Energy Procedia 1,4715-4718 (2009).

25. E. Pischkea, et al, From Kyoto to Paris: Measuring renewable energy policy regimes in Argentina, Brazil, Canada, Mexico and the United States,Energy Res. Soc. Sci. 50, 82 91 (2019).

26. C. Boomsma, E. Mors, Great green bribe or good practice? Community compensation in the context of Carbon Capture and Storage. International Association People Environment Studies Conference, Italy, 8-13 July 2018. Available at: https://www.alignccus.eu/sites/default/files/BoomsmaTerMors2018\%20I APS\%20abstract.pdf (2018)

27. N. Gaurina-Medimyrec, M. Novak, Carbon Capture and Storage (CCS): Geological Sequestration of $\mathrm{CO} 2$ Available at: https://www.intechopen.com/online-first/carboncapture-and-storage-ccs-geological-sequestration-of-co2 (2019).

28. P. Singha, M. Haines, A Review of Existing Carbon Capture and Storage Cluster Projects and FutureOpportunities, Energy Procedia 63, 7247-7260 (2014).

29. E. Koytsoumpa, C. Bergins, E. Kakaras, The CO2 economy: Review of CO2 capture and reuse technologies, J. Supercrit. Fluids 132, 3-16 (2017).

30. A. Ilinova, A. Cherepovitsyn, O. Yevseyeva, Stakeholder Management: An Approach in CCS Projects, Resources, 7(4), 8 (2019).

31. G. Lavrenchenko, A. Kopytin, Prospects for the improvement and widespread use of CCS technologies, Tekhnicheskie Gasy. [Industrial Gases] 2, 3-15 (2015).

32. G. Karkashadze, Yu. Harin, Modern approaches to carbon dioxide disposal technologies in coal seams and rock masses, Mining information and analytical Bulletin (scientific and technical journal)13, 291-306 (2007).

33. S. Pereverzeva, P. Konosavsky, A. Tudvachev, I. Kharkhordin, Storage of industrial carbon dioxide emissions into geological structures, (in Russian), Vestnik of SaintPeterburg University 7 (1), 5-17 (2014).

34. P. Tcvetkov, A. Cherepovitsyn, P. Fedoseev, Public perception of carbon capture and storage: A state-of-the-art overview, Heliyon, 512 (2019). Available at: https://www.sciencedirect.com/science/article/pii/S2405844019365041

35. J. Lipponen, et al, The Politics of Large-scale CCS Deployment, Energy Procedia 114, 7581-7595 (2017). 
36. D. Reiner, J. Desbarats, P. Upham, H. Riesch, Review of the public participation practices for CCS and non-CCS projects in Europe, Report of the FP7 project «NearCO2» 11, 125 (2010).

37. B. Terwel, F. Koudenburg, E. Ter Mors, Public responses to community compensation: the importance of prior consultations with local residents, Journal of Community \& Applied Social Psychology 24(6), 479-490 (2013).

38. R. Malek, Results of due diligence study phase 3.5 on feasibility of Gorgon $\mathrm{CO} 2$ Sequestration Petroleum in Western Australia, Western Australian Department of Mines and Petroleum, 13-17 (2009).

39. Y. Vasilev, P. Vasileva, A. Tsvetkova, International review of public perception of ccs technologies, 19th International Multidisciplinary Scientific GeoConference SGEM, 19 (5.1.), 415-422 (2019). 